\title{
PENERAPAN MODEL REGRESI KUANTIL UNTUK MENGANALISIS HUBUNGAN PANJANG-BERAT IKAN NILA (Oreochromis niloticus) DI KOLAM IBAT PUNTEN, BATU
}

\author{
Evellin Dewi Lusiana $^{\mathrm{a}, \mathrm{b}, *}$, Muhammad Musa ${ }^{\mathrm{a}, \mathrm{b}}$, dan Syahril Ramadhan \\ ${ }^{a}$ Fakultas Perikanan dan Ilmu Kelautan, Universitas Brawijaya, Malang, Indonesia \\ ${ }^{\mathrm{b}}$ AquaRES Research Group, Universitas Brawijaya, Malang, Indonesia \\ *Corresponding author: evellinlusiana@ub.ac.id
}

\begin{abstract}
Abstrak
Ikan Nila (Oreochromis niloticus) merupakan salah satu komoditas perikanan air tawar yang banyak digemari dan bersifat potensial dalam proses budidaya. Permintaan terhadap komoditas ini selalu meningkat, sehingga menjadi kesempatan bagi para pembudidaya untuk meningkatkan hasil produksi. Kondisi lingkungan perairan berperan penting dalam kelancaran proses budidaya ikan. Adapun salah satu cara yang bisa digunakan untuk menilai kondisi lingkungan perairan adalah melalui analisis hubungan panjang-berat. Hasil dari analisis hubungan tersebut yakni berupa faktor kondisi allometris dapat digunakan untuk menilai karakteristik fisiologis ikan, siklus hidup, kondisi lingkungan sekitar dan ketersediaan makanan. Umumnya, hubungan panjang berat dianalisis dengan pendekatan regresi linier sederhana di mana memiliki kelemahan yaitu sangat dipengaruhi oleh nilai ekstrim/outlier sehingga tidak mampu menggambarkan distribusi data secara keseluruhan. Oleh karena itu, penelitian ini bertujuan untuk menerapkan alternatif metode lain yaitu regresi kuantil yang mampu menjelaskan hubungan panjang-berat ikan secara lebih menyeluruh. Data sampel ikan yang digunakan berasal dari kolam IBAT Punten, Batu yang merupakan salah satu sentra pembenihan dan budidaya Ikan Nila. Hasil penelitian menunjukkan bahwa secara umum faktor kondisi allometris Ikan Nila di IBAT Punten bersifat allometris negatif, artinya pertambahan berat lebih kecil dibandingkan pertambahan panjang ikan atau dengan kata lain ikan cenderung kurus. Selain itu, dari analisis regresi kuantil didapatkan kecenderungan bahwa semakin besar ukuran ikan Nila maka nilai faktor kondisi allometris semakin kecil. Hal ini dikarenakan ikan Nila dewasa lebih rentan terhadap perubahan lingkungan dibandingkan dengan ikan Nila yang lebih kecil.
\end{abstract}

Keywords: faktor kondisi allometris, hubungan panjang-berat, regresi kuantil

\begin{abstract}
Tilapia (Oreochromis niloticus) is freshwater fishery commodity and potential in the cultivation process. Demand for this commodity is always increasing, so that it becomes an opportunity for farmers to increase the production. The condition of the aquatic environment also plays an important role in the process of fish aquaculture. One way that can be used to assess the condition of the aquatic environment is through the analysis of long-weight relationships. The results of the relationship analysis in the form of allometric condition can be used to assess the physiological characteristics of fish, life cycle, environmental conditions and food availability. Generally, the relationship is analyzed using simple linear regression approach where the weaknesses are strongly influenced by outliers so that they cannot describe the overall data distribution. Therefore, this study aims to apply alternative methods, namely quantile regression which is able to explain the length-weight relationship more thoroughly. The used tilapia fish samples were taken from IBAT Punten, Batu. Based on the research, it was found that generally allometric conditions of Tilapia in IBAT Punten were negative allometric, meaning that weight gain was smaller than the length of fish or in other words fish tend to be thin. In addition, from the quantile regression analysis, it was found that the greater the size of Tilapia, the smaller the allometric condition faktor. This is because adult tilapia are more susceptible to environmental changes compared to smaller tilapia fish.
\end{abstract}

Keywords: allometric condition, length-weight relationship, quantile regression 


\section{PENDAHULUAN}

Ikan Nila (Oreochromis niloticus) merupakan salah satu komoditas perikanan air tawar yang banyak digemari dan bersifat potensial dalam proses budidayanya. Hal ini disebabkan Ikan Nila dapat mudah berkembang biak, mampu menerima pakan tambahan dengan baik, memiliki survival rate tinggi, dapat mentolerir kondisi salinitas dengan range yang cukup luas, bernilai ekonomis tinggi [1].

Menurut [2], permintaan pasar terhadap komoditas ikan Nila selalu mengalami peningkatan sehingga menjadi kesempatan bagi para pembudidaya untuk mengembangkan bisnis budidaya ikan Nila. Akan tetapi, faktor yang menjadi kendala dalam proses budidaya ini adalah ketersediaan lahan yang terbatas dan kualitas benih. Menurut [3], benih yang unggul akan berpengaruh terhadap hasil produksi budidaya serta dapat diterima dengan baik oleh pasar. Kualitas benih seperti tingkat kelangsungan hidup atau survival rate sangat dipengaruhi oleh kondisi lingkungan perairan yaitu suhu, $\mathrm{pH}$, dan salinitas [4].

Salah satu cara yang dapat digunakan untuk menilai kondisi lingkungan perairan budidaya ikan adalah dengan melakukan analisis terhadap hubungan panjang berat. Hubungan panjang dan berat adalah suatu proses kenaikan berat ikan menurut panjang ikan dalam periode waktu tertentu. [5] menyebutkan bahwa pengukuran panjang berat ikan bertujuan untuk mengetahui variasi berat dan panjang tertentu dari ikan secara individual atau kelompok-kelompok individu sebagai suatu petunjuk tentang kegemukan, kesehatan, produktifitas dan kondisi fisiologis termasuk perkembangan gonad. Selain itu, berdasarkan hubungan panjang berat ikan dapat diperoleh suatu konstanta yang disebut dengan faktor kondisi allometris untuk menentukan bilamana kondisi ikan bersifat isometric atau allometrik. Faktor kondisi alometrik adalah nilai yang menunjukkan perbandingan laju pertumbuhan panjang dengan berat ikan. Nilai dari konstanta ini menunjukkan karakteristik fisiologis dari ikan terutama kematangan, spawning, siklus hidup, kondisi lingkungan sekitar dan ketersediaan makanan pada ekosistem perairan [6].

Bentuk persamaan hubungan panjang berat secara umum dapat dituliskan dalam persamaan (1) berikut:

$$
W=a \cdot L^{b}
$$

di mana:

$\mathrm{W} \quad=$ berat tubuh ikan (gram)

$\mathrm{L} \quad=$ panjang ikan $(\mathrm{cm})$

a $\quad=$ koefisien intersep

b $\quad=$ koefisien slope (faktor kondisi)

Koefisien slope $(b)$ disebut sebagai faktor kondisi allometrik. Terdapat tiga kemungkinan nilai $b$ yaitu

$-b>3 \rightarrow$ terjadi apabila pertumbuhan berat lebih cepat dibanding dengan pertumbuhan panjangnya

- $b<3 \rightarrow$ pertumbuhan panjang lebih cepat dibanding dengan pertumbuhan beratnya

- $b=3 \rightarrow$ pertumbuhan panjang dan berat seimbang atau disebut isometris.

Faktor kondisi allometrik mengindikasikan kondisi lingkungan perairan, di mana semakin tinggi nilai $b$ maka menunjukkan kondisi perairan yang semakin baik [7]. Selain itu, faktor lingkungan juga dapat mengakibatkan nilai $b$ menjadi rendah. Lingkungan perairan yang sudah mengalami pencemaran dapat mempengaruhi rendahnya faktor kondisi.

Bentuk persamaan tersebut bersifat nonlinear, sehingga untuk mempermudah analisis dilakukan transformasi sebagai berikut

$$
\ln (W)=\ln (a)+b \ln (L)
$$

persamaan (2) setara dengan persamaan regresi linier sederhana

$$
Y=a^{\prime}+b . X
$$

di mana:

$$
\begin{array}{ll}
\mathrm{Y} & =\ln (\mathrm{W}) \\
\mathrm{X} & =\ln (\mathrm{L}) \\
\mathrm{a}, & =\ln (\mathrm{a})
\end{array}
$$

koefisien a' dan $b$ diperoleh dengan persamaan (3) dan (4) 


$$
\begin{aligned}
& b=\frac{n \sum_{i=1}^{n} X_{i} Y_{i}-\sum_{i=1}^{n} X_{i} \sum_{i=1}^{n} Y_{i}}{n \sum_{i=1}^{n} X_{i}^{2}-\left(\sum_{i=1}^{n} X_{i}\right)^{2}} \\
& a^{\prime}=\bar{Y}-b \bar{X} \rightarrow a=\exp \left(a^{\prime}\right)
\end{aligned}
$$

dari persamaan (3), analisis hubungan panjang berat kemudian biasanya dianalisis menggunakan metode Ordinary Least Square (OLS) sebagaimana yang sudah banyak dilakukan oleh para peneliti seperti yang dilakukan oleh [8] yang menganalisis hubungan panjang berat pada Lobster, serta [9] pada Ikan Bilih. Metode OLS adalah metode estimasi parameter regresi yang bersifat meminimumkan kuadrat dari selisih antara nilai pengamatan dengan nilai duga [10]

Namun, penggunaan analisis regresi linier sederhana dengan metode OLS memiliki kekurangan, yaitu analisis ini tidak dapat menggambarkan distribusi data secara menyeluruh dan rentan terhadap kehadiran pencilan atau outlier [11]. Hal ini disebabkan metode OLS adalah metode estimasi parameter yang berbasis pada nilai rata-rata variabel respon (conditional mean), sehingga data-data yang terletak jauh dari nilai rata-rata tidak terepresentasi dengan baik melalui metode ini [12]. Dengan demikian, analisis hubungan panjang-berat membutuhkan teknik analisis lain. Salah satu analisis yang bisa digunakan analisis regresi kuantil. Model regresi kuantil memungkinkan untuk menghasilkan model regresi dari beberapa kuantil variabel respon yang diinginkan, sehingga model yang dihasilkan dapat lebih menggambarkan distribusi data secara lebih lengkap [12]. Adapun model umum regresi kuantil yakni [13]

$$
Q_{Y}(p \mid \mathbf{X})=\mathbf{X}^{\mathbf{t}} \boldsymbol{\beta}(p)
$$

di mana: $\boldsymbol{\beta}(p)$ merupakan vector parameter regresi yang tergantung pada kuantil ke- $p$ $(0<\mathrm{p}<1)$.

Estimasi parameter pada persamaan (5) dapat diperoleh dengan meminimumkan persamaan (6) berikut

$$
\arg \min _{\beta \in R^{p}} \sum_{i=1}^{n} \rho_{p}\left(Y_{i}-\mathbf{X}_{i}^{t} \boldsymbol{\beta}(p)\right)
$$

di mana: $\rho_{p}(\mu)=\mu[p-I(\mu<0)]$ disebut sebagai check function. Penyelesaian permasalahan minimasi tersebut menggunakan bantuan pemrograman linier [14].

Berdasarkan uraian-uraian tersebut, maka penelitian ini bertujuan untuk menerapkan model regresi kuantil untuk menganalisis hubungan panjang-berat Ikan Nila. Adapun data panjang berat Ikan Nila yang diambil berasal dari salah satu pusat pembenihan dan pembesaran Ikan Nila di Jawa Timur yang terletak di IBAT Punten, Batu.

\section{METODE PENELITIAN}

\section{Sumber Data}

Data yang digunakan dalam penelitian berasal dari pengukuran panjang dan berat Ikan Nila yang dibudidayakan di Instalasi Budidaya Air Tawar (IBAT) Punten, Batu selama kurun waktu Februari-April 2018. Adapun jumlah sampel ikan yang digunakan sebanyak 75 ekor.

\section{Metode Analisis}

Metode analisis yang digunakan dalam penelitian ini mengikuti tahapan-tahapan sebagai berikut

1. Melakukan analisis deskriptif dengan histogram terhadap variabel penelitian yaitu panjang dan berat Ikan Nila

2. Mengidentifikasi keberadaan outlier dengan Cooks distance

$$
D_{i}=\frac{\left(\hat{\boldsymbol{\beta}}_{(i)}-\hat{\boldsymbol{\beta}}\right)^{\prime} \mathbf{X}^{\prime} \mathbf{X}\left(\hat{\boldsymbol{\beta}}_{(i)}-\hat{\boldsymbol{\beta}}\right)}{(k+1) s^{2}}
$$

Di mana:

$\hat{\boldsymbol{\beta}}_{(i)}=$ vektor estimasi parameter regresi

ketika pengamatan ke-i dihilangkan

$\hat{\boldsymbol{\beta}}=$ vektor estimasi parameter regresi

$\mathbf{X}=$ matriks variabel prediktor 
$\mathrm{k} \quad=$ banyaknya variabel prediktor

$s^{2} \quad=$ ragam nilai estimasi variabel respon

pengamatan yang memiliki nilai Cooks distance lebih besar dari 4 kali rata-rata diklasifikasikan sebagai nilai ekstrim atau outlier [15].

3. Mengestimasi faktor kondisi allometris dalam persamaan hubungan panjang berat dengan metode Ordinary Least Square (OLS) atau regresi linier sederhana

4. Mengestimasi faktor kondisi allometris dengan analisis regresi kuantil

Membandingkan hasil estimasi antara regresi linier sederhana dan regresi kuantil dengan kuantil (p) yang menunjukkan klasifikasi berat ikan yaitu 0.05 (sangat ringan), 0.25 (ringan), 0.50 (sedang), 0.75 (berat) dan 0.95 (sangat berat). Proses analisis dilakukan dengan bantuan software $\mathrm{R}$ versi 3.1.0.

\section{HASIL DAN PEMBAHASAN}

\section{Evaluasi Deskriptif Panjang dan Berat Ikan Nila di IBAT Punten, Batu}

Distribusi atau persebaran panjang dan berat ikan Nila yang ada di kolam budidaya IBAT Punten, Batu disajikan pada Gambar 1 dan 2 berikut:

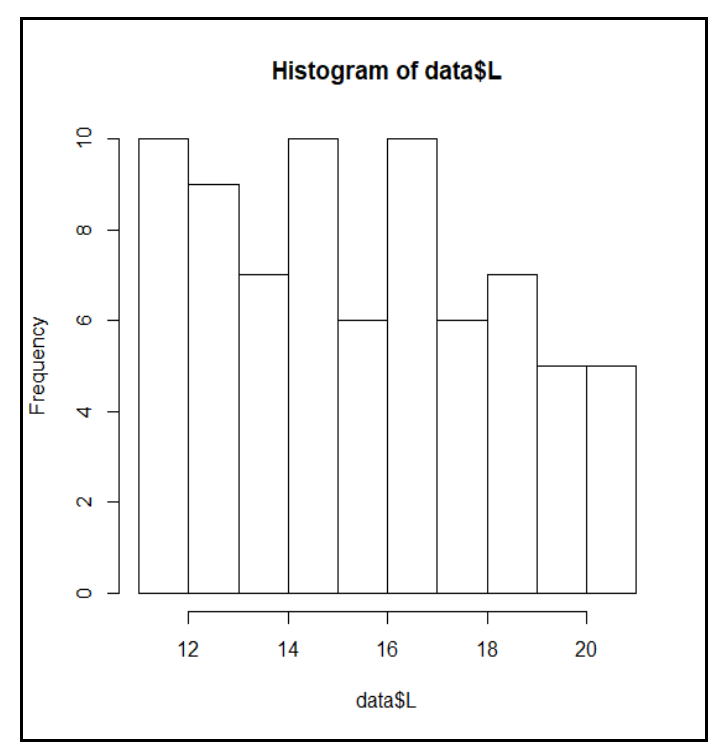

Gambar 1. Histogram Panjang Ikan Nila
Dari Gambar 1 dapat diketahui bahwa ukuran panjang Ikan Nila yang dijadikan sampel penelitian ini berkisar antara 12-20 $\mathrm{cm}$, di mana distribusi variabel panjang ini bersifat merata. Artinya frekuensi setiap kelas panjang relatif hamper sama. Adapun kelas panjang yang terbesar memiliki frekuensi yang lebih rendah dibandingkan kelas panjang lainnya.

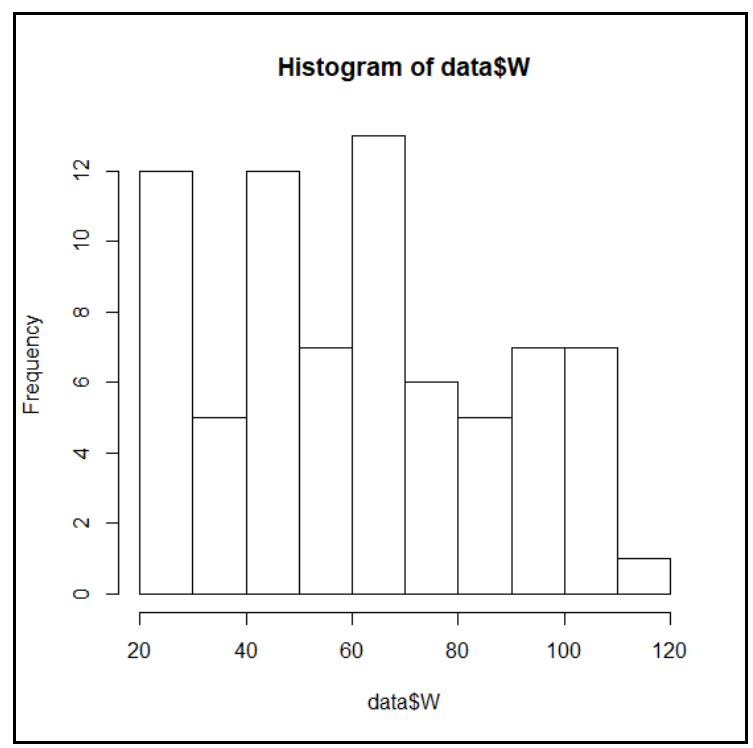

Gambar 2. Histogram Berat Ikan Nila

Gambar 2 memperlihatkan bahwa berat ikan Nila dalam sampel penelitian ini memiliki range sebesar 20-120 gram. Apabila dibandingkan dengan distribusi panjang, maka distribusi berat Ikan Nila ini cenderung lebih bervariasi dengan frekuensi antar kelas berat yang berbeda-beda. Sebagian besar sampel ikan yang digunakan memiliki berat sekitar 20, 40, dan 70 gram. Sedangkan ikan Nila yang mampu mencapai berat sekitar 120 gram hanya 1 ekor.

\section{Identifikasi Outlier dengan Cooks Distance}

Gambar 3 berikut menyajikan scatterplot dari nilai Cooks distance setiap pengamatan.

Berdasarkan Gambar 3 dapat dilihat bahwa terdapat dua pengamatan yang dapat dikategorikan sebagai outlier yaitu pengamatan ke 2 dan 3, di mana kedua pengamatan ini memiliki nilai Cooks distance lebih dari 4 kali nilai rata-rata. Hal ini menunjukkan bahwa penggunaan regresi 
linier sederhana tidak dianjurkan karena analisis regresi ini sangat dipengaruhi oleh keberadaan outlier.

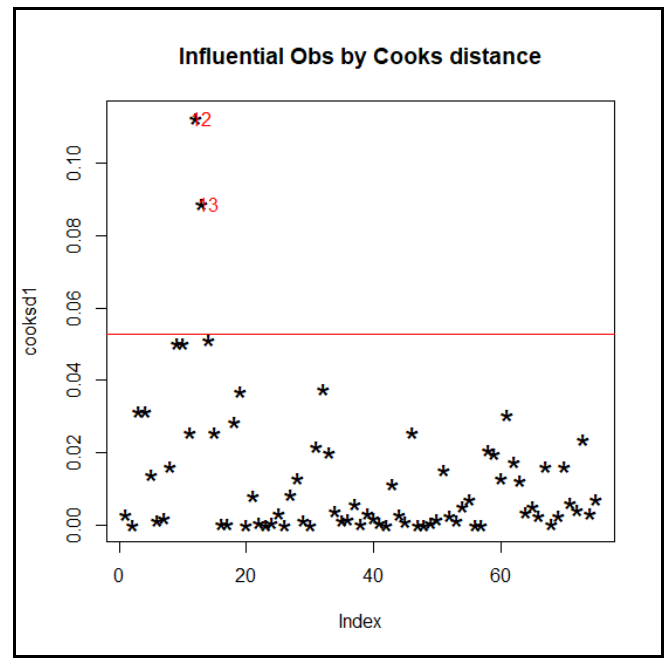

Gambar 3. Scatterplot Nilai Cooks Distance

\section{Hasil Estimasi Hubungan Panjang-Berat Ikan Nila Dengan Regresi Linier Sederhana dan Regresi Kuantil}

Berikut ini disajikan ringkasan estimasi parameter dari model hubungan panjang berat dengan menggunakan regresi linier sederhana dan regresi kuantil.

Tabel 1. Hasil Estimasi Parameter Model Hubungan Panjang-Berat

\begin{tabular}{ccccc}
\hline \multicolumn{2}{c}{ Model } & Slope & SE & P-value \\
\cline { 1 - 2 } \multicolumn{2}{c}{ Regresi linier } & 2.372 & 0.071 & 0.000 \\
\cline { 1 - 2 } Regresi & 0.05 & 2.612 & 0.137 & 0.000 \\
kuantil & 0.25 & 2.417 & 0.134 & 0.000 \\
& 0.5 & 2.358 & 0.080 & 0.000 \\
& 0.75 & 2.263 & 0.080 & 0.000 \\
& 0.95 & 2.177 & 0.141 & 0.000 \\
\hline
\end{tabular}

Berdasarkan Tabel 1, dapat diketahui bahwa nilai faktor kondisi allometris dari hasil analisis regresi linier sederhana sebesar 2.372 yang artinya apabila panjang tubuh ikan bertambah $1 \%$, maka akan mengakibatkan berat ikan meningkat sebesar $2.372 \%$. Nilai ini menunjukkan bahwa faktor kondisi allometris ikan nila bersifat llometrik negatif. Atau dengan kata lain, pertambahan berat lebih kecil daripada pertambahan panjang.
Di sisi lain, hasil analisis regresi kuantil menunjukkan bahwa nilai faktor kondisi allometris antar kuantil berbeda-beda, di mana secara keseluruhan memperlihatkan bahwa faktor kondisi ini bersifat allometrik negatif. Selain itu, dari hasil tersebut juga dapat dilihat bahwa semakin besar nilai kuantil maka nilai faktor kondisi allometris semakin kecil. Pemodelan dengan nilai kuantil 0.05 menunjukkan analisis dilakukan untuk data berat ikan sekitar 26.69 gram, kuantil 0.25 untuk data berat ikan kurang lebih 43.50 gram, kuantil 0.50 sebesar 62 gram, serta kuantil 0.75 diperuntukan untuk analisis data berat ikan sebesar 81.5 gram. Adapun pemodelan untuk kuantil 0.95 menggunakan data berat ikan kurang lebih 105 gram. Dengan demikian dapat dikatakan bahwa semakin besar ukuran berat Ikan Nila, maka bentuk proporsi tubuhnya cenderung semakin kurus karena pertambahan berat lebih kecil dari pertambahan panjang. Kondisi tersebut menunjukkan bahwa ikan-ikan Nila yang berukuran besar lebih rentan terhadap kondisi lingkungan perairan dibandingkan ikan yang berukuran kecil, sehingga penyerapan pakannya kurang optimal. Hasil penelitian ini sejalan dengan [16] yang menyatakan bahwa Ikan nila kecil atau benih cenderung lebih cepat menyesuaikan diri terhadap kenaikan salinitas dibandingkan ikan nila yang berukuran besar, serta [17] yang menyebutkan bahwa benih ikan nila akan lebih tahan terhadap perubahan lingkungan dibandingkan dengan ikan nila dewasa.

\section{KESIMPULAN DAN SARAN}

\section{Kesimpulan}

Berdasarkan hasil penelitian ini dapat disimpulkan bahwa sampel ikan Nila yang diperoleh dari kolam budidaya IBAT Punten, Batu memiliki memiliki faktor kondisi yang bersifat allometris negatif baik dengan analisis hubungan panjang-berat menggunakan regresi linier sederhana maupun regresi kuantil. Namun, pendekatan dengan regresi linier sederhana kurang tepat karena pada data yang digunakan mengandung outlier. Sedangkan hasil analisis dengan regresi kauntil 
didapatkan hasil hubungan panjang-berat yang lebih menyeluruh dimana dapat diketahui bahwa semakin besar ukuran berat ikan Nila, faktor kondisi allometrisnya semakin kecil. Hal ini dikarenakan ikan Nila dewasa cenderung lebih rentang terhadap perubahan kondisi lingkungan dibandingkan ikan Nila yang berukuran lebih kecil.

\section{Saran}

Dari hasil penelitian yang diperoleh, maka saran yang dapat disampaikan yaitu perlunya pengawasan dan kontrol kondisi lingkungan perairan yang lebih ketat pada kolam ketika ukuran Ikan Nila mencapai ukuran yang semakin besar. Sebab, semakin besar ukuran ikan Nila maka semakin rentan terhadap perubahan lingkungan.

\section{UCAPAN TERIMAKASIH}

Penelitian ini didanai melalui program Hibah Penelitian Dosen dengan dana PNBP Fakultas Perikanan dan Ilmu Kelautan Universitas Brawijaya Tahun 2018. Penulis mengucapkan terima kasih kepada semua pihak yang telah membantu terselesaikannya penelitian ini dengan baik.

\section{DAFTAR PUSTAKA}

[1] KKP, Informasi Kelautan dan Perikanan, Pusat Data, Statistik dan Informasi Jakarta, 2010.

[2] FAO, FAO Fisheries \& Aquaculture Oreochromis niloticus, FAO Corporate Document Respository, 2011.

[3] F. Sau, M.m. Sarma, W. Trilaksani, "Penerapan Cara Pembenihan Ikan yang Baik dalam Meningkatkan Kinerja UMKM Pembenihan Udang di Kabupaten Barru, Provinsi Sulawesi Selatan", Manajemen IKM, 12 (2017) 1624.

[4] Aliyas, S. Ndobe, Z.R. Ya'la, "Pertumbuhan dan Kengasungan Hidup Ikan Nila (Oreochromis sp.) Yang Dipelihara Pada Media Bersalinitas",
Jurnal Sains dan Teknologi Tadulako, 5 (2016) 19-27.

[5] Mulfizar, Z.A. Muchlisin, I. Dewiyanti, "Hubungan panjang berat dan faktor kondisi tiga jenis ikan yang tertangkap di perairan Kuala Gigieng, Aceh Besar, Provinsi Aceh", DEPIK, 1 (2012) 1-9.

[6] H. Asadi, M. Sattari, Y. Motalebi, M. Zamani-Faradonbeh, A. Gheytasi, "Length-weight relationship and condition factor of seven fish species from Shahrbijar River, Southern Caspian Sea basin, Iran", Iranian Journal of Fisheries Sciences, 16 (2017) 733-741.

[7] M. Arwani, Analisis Pengkajian Pertumbuhan Ikan Belanak (Mugil Dussumieri) Di Perairan Ujung Pangkah, Jawa Timur, Fakultas Perikanan dan Ilmu Kelautan, IPB, Bogor, 2002.

[8] M. Fauzi, A.P. Prasetyo, I.T. Hargiyanto, F. Satria, A.A. Utama, "Hubungan Panjang Berat Dan Faktor Kondisi Lobster Batu (Panulirus penicillatus) di Perairan Selatan Gunung Kidul", Bawal, 5 (2013) 97-102.

[9] C. Umar, E.S. Kartamihardja, "Hubungan Panjang Berat, Kebiasaan Makan dan Kematangan Gonad Ikan Bilih (Mystaecoleucus padangensis) di Danau Toba, Sumatera Utara", Bawal, 3 (2011) 351-356.

[10] E. Kusfiva, Analisis Regresi Linier Berganda Dengan Metode OLS, Probit dan Tobit, Jurusan Statistika, Institut Teknologi Sepuluh Nopember Surabaya, Surabaya, 2000.

[11] M. Wang, L. Zhang, "A Bayesian Quantile Regression Analysis of Potential Risk Factors for Violent Crimes in USA", Open Journal of Statistics, 2 (2012) 73-78.

[12] C. Chen, An Introduction to Quantile Regression and The QUANTREG Procedure, 2005. 
[13] R. Koenker, K. Hallock, "Quantile Regressions", Journal of Economic Perspectives, 15 (2001) 143-156.

[14] B. Fitzenberger, P. Winker, "Improving the Computation of Censored Quantile Regression Estimators", CSDA, 52 (2007) 88-108.

[15] A. Zakaria, N.K. Howard, B.K. Nkansah, "On the detection of influential outliers in linear regression analysis", American
Journal of Theoretical and Applied Statistics, 3 (2014) 100-106.

[16] R.S.V. Pullin, J.L. Maclean, "Analysis of Research for the Development of Tilapia Farming: an Interdisciplinary Approach Is Lacking ", Netherlands Journal of Zoology, 42 (1991) 512-524.

[17] R. Suyanto, Pembenihan dan Pembesaran Nila, Penebar Swadaya, Jakarta, 2010. 